\title{
Clément Marot: o principal editor antigo do corpus atribuído a François Villon
}

\author{
Daniel Padilha Pacheco da Costa ${ }^{1}$
}

\begin{abstract}
RESUMO: Neste artigo, pretende-se compreender os critérios históricos que orientaram as primeiras edições do corpus atribuído a François Villon. Embora as edições modernas utilizem critérios editoriais distintos (baseados na biografia do seu suposto autor empírico), elas retomam os contornos da principal edição antiga das Obras de François Villon de Paris (1532) por Clément Marot. Publicado postumamente, aquele corpus não recebeu nenhuma edição autorizada, mas foi em grande medida o resultado do trabalho coletivo dos seus primeiros editores. A partir das metáforas do véu e do corpo para o texto, Marot fundou a sua edição numa rigorosa interpretação do sentido moral do corpus. Desse modo, a edição Marot foi cronologicamente estruturada não em torno da "biografia", mas da vida exemplar da personagem do vilão arrependido, segundo a cosmologia cristã da queda e redenção.
\end{abstract}

PALAVRAS-CHAVE: François Villon; Corpus medieval; Conceito de autoria; Clément Marot; Edições antigas; Gênero biográfico.

\begin{abstract}
In this paper, we intend to understand the historical criteria that guided the first editions of François Villon's poetic corpus. Although modern editions use different editorial criteria (based on the biography of its hypothetical empirical author), they reproduce the shape of the main old edition of François Villon's Works (1532) by Clément Marot. Published posthumously, that corpus did not receive any authorized edition, but it was largely the result of the collective work of its first editors. Using the metaphors of veil and body to refer the poetic text, Marot has founded his publishing upon a rigorous interpretation of the corpus' moral sense. Thus, Marot's edition is chronologically builded upon the exemplary life of the villain's repentance, according to the Christian cosmology of the fall and redemption.
\end{abstract}

KEYWORDS: François Villon; Medieval corpus; Concept of authorship; Clément Marot; Old editions; Biographical genre.

\section{A doutrina do véu da escola de Chartres}

A metáfora do tecido para o texto escrito foi utilizada desde o surgimento da imprensa pelos editores do final do séc. XV. Essa metáfora não foi inventada pelos primeiros editores, mas tomada emprestado dos comentadores medievais. Os comentadores pertencentes à Escola de Chartres, em particular, utilizavam para o texto escrito a metáfora do véu (integumentum). As ficções poéticas inventadas pelos autores antigos foram por eles interpretadas como um véu fabuloso encobrindo verdades morais. Nesse sentido, a doutrina do véu concebe as ficções poéticas em sentido técnico como narrações fabulosas alegorizando preceitos morais, como afirma o comentário "Sobre a Tebaida" (Super Thebaiden), que, na época, era atribuído a Fulgêncio:

Professor do curso de Tradução da Universidade Federal de Uberlândia (UFU). Doutor pelo Departamento de Letras Modernas da USP (Francês), com um período sanduíche na Université Paris-Sorbonne (Paris IV). Email: <daniel.padilha.costa@usp.br>. 
Eu retrato com grande admiração a insondável prudência dos poetas e o seu imperecível engenho; eles que, sob o véu sedutor da ficção poética, introduziram com utilidade uma série de preceitos morais ${ }^{2}$ (PSEUDO-FULGÊNCIO, 2004, p. 74, tradução nossa).

Os comentadores medievais pertencentes à Escola de Chartres se referem às ficções poéticas por meio da metáfora do véu utilizado por uma dama. Os preceitos morais parcialmente ocultados são metaforizados pelo rosto de uma bela dama que veste um véu sedutor. Essa metáfora é dotada de um caráter sensual implícito desde os filósofos gregos antigos que, definindo a verdade através da palavra desocultamento (alétheia), frequentemente associaram-na ao triunfo viril sobre o pudor feminino. Os comentadores medievais entendiam a verdade em sentido neoplatônico, como a visão intelectual (isto é, como a "visão pela mente"), por meio da qual, depois de muito esforço, o sábio finalmente contempla o mundo transcendente das ideias.

Mas os teólogos medievais tiveram que adaptar a doutrina neoplatônica da verdade ao dogma cristão da verdade revelada. Embora a verdade já esteja desde sempre dada na Eternidade, ela só foi revelada pelas Sagradas Escrituras: Deus é o Verbo. Segundo a doutrina medieval dos dois livros, o mundo, como a Bíblia, constitui um livro. Da mesma forma que o mundo é hierarquizado segundo os graus de perfeição, as disciplinas do conhecimento também o são. Para além do trivium e do quadrivium, cabe à teologia o monopólio da interpretação da verdade revelada.

Para interpretar o sentido intrínseco das coisas, os teólogos medievais procedem como comentadores, retirando o véu das palavras escritas na Bíblia para compreender o seu sentido moral. O Novo e o Velho Testamento seriam um dicionário definindo o sentido intrínseco das coisas criadas. Assim, o sentido espiritual das coisas deve ser interpretado a partir da verdade revelada pelas Sagradas Escrituras. A metáfora do mundo como um livro é um lugar comum da literatura medieval, como testemunham as duas estrofes iniciais de Rhythmus Alter, de Alain de Lille:

Do mundo toda criatura,

Como um livro e uma pintura,

Está no nosso espelho:

De nossa vida e nossa morte,

De nosso estado e nossa sorte

É fiel selo.

Retrata esse estado a rosa,

Que a nossa vida glosa:

De manhazinha, ela deflora;

Florescida, a flor que aflora

2 "Poetarum inuestigabilem prudentiam ingeniique eorum uenam inmarcescibilem non sine grandi ammiratione retracto, qui sub blanditorio poeticae fictionis tegumento moralium seriem institutionum utiliter inseruerunt".

Clément Marot: o principal editor antigo do corpus atribuído a François Villon 
No ocaso posa ${ }^{3}$

(apud ECO, 1987, tradução nossa)

Alain de Lille ilustrou no poema o próprio método hermenêutico desenvolvido pelos teólogos para interpretar o sentido espiritual das coisas. O poema é inteiramente construído com base em alegorias de semelhança: a rosa é alegoria de criatura, o mundo, de imagem, o dia, de vida e a luz, de Deus. Todas as criaturas são comparadas com a rosa que, como exemplo da transitoriedade do mundo temporal, irradia desde o desabrochar na alvorada até o murchar no crepúsculo a beleza da Criação de Deus, metaforizado pela luz. Segundo a concepção neoplatônica, o mundo físico é um reflexo embaçado do mundo espiritual. As criaturas são um espelho para o homem, que é a única criatura capaz de compreender racionalmente o sentido da salvação inscrita por Deus no destino do gênero humano.

Deus fala pelas coisas, e os homens por palavras: ao designar as coisas criadas, a linguagem humana é signo de signos. Assim, as ficções poéticas podem apenas ilustrar a verdade revelada, produzindo significações reduzidas ao sentido histórico das coisas. Nas palavras de São Tomás de Aquino: "As ficções poéticas não têm outra finalidade senão significar; é porque uma tal significação não ultrapassa o nível do sentido histórico" (apud HANSEN, 2006 , p. 123). Assim, o poeta não pode ambicionar mais do que repetir o Verbo expresso na Bíblia, procurando representar o sentido moral da existência humana na história da salvação, como demonstra o poema de Alain de Lille.

Os comentadores da Escola de Chartres, por sua vez, baseiam-se nos preceitos morais presentes nas Sagradas Escrituras para interpretar as ficções poéticas. A retomada da metáfora do véu para o texto escrito pelos primeiros editores modernos mostra que eles procuraram fundar a sua atividade sobre a interpretação do sentido moral das composições. $\bigcirc$ editor não deixa de ser um comentador do texto, pois ele não pode delimitar o contorno das obras sem ter primeiramente desvelado, por meio de uma rigorosa exegese, o seu sentido moral. Como afirma Bernard Cerquiglini (1989), o editor e o autor não se distinguem de maneira radical à época do surgimento da prensa, no final do séc. XV e início do séc. XVI.

Fundadas sobre uma concepção precisa de comentário, as edições são elas mesmas complementares ao trabalho de composição, entendido como o meticuloso encobrimento do sentido moral sob a ficção poética. As primeiras edições do corpus atribuído a François Villon são extremamente ilustrativas disso, elas que foram realizadas precocemente já no final do séc. XV e que, durante a primeira metade do séc. XVI, receberam dezenas de reedições. Neste artigo, pretende-se mostrar como os seus primeiros editores definiram os principais contornos desse corpus com base nessa concepção de texto como véu encobrindo a vida exemplar da personagem do vilão arrependido.

"Omnis mundi criatura/ Quasi liber et pictura/ Nobis est in speculum/ Nostrae vitae, nostrae mortis/ Nostri status, nostrae sortis/ Fidele signaculum// Nostrum statum pingit rosa/ Nostrae vitae lectio/ Quae dum primo mane floret/ Defloratus flos effloret/Vespertino senio". 


\section{O nome do autor "François Villon"}

Os seus diversos editores antigos no fim do séc. XV e início do séc. XVI desempenharam um papel essencial na constituição de seu corpo poético. Chamada por Pierre Champion (1924) de "a mais antiga edição de François Villon", a primeira edição que chegou até nós do seu corpus foi publicada em Paris por Pierre Levet, que a intitulou: O Grande Testamento de Villon e o Pequeno. Seu codicilo. O jargão e suas baladas (VILLON, 1489). Como é anunciado no próprio título, a edição Levet é constituída por dois poemas longos em forma de testamentos e por quatorze formas fixas esparsas, incluídas as seis Baladas em jargão.

O corpus de Villon foi frequentemente incluído em coletâneas de composições burlescas e poéticas da época. Foi isso o que aconteceu desde a sua primeira edição por Pierre Levet, que publicou Villon juntamente com dois outros testamentos burlescos, com uma farsa e com uma arte de segunda retórica. Villon foi publicado por Levet com a Farsa de Pierre Pathelin, O Testamento de Testa Vinhos, rei dos bêbados, O Testamento de Barreiz, capitão dos Bretões e um manual de retórica chamado Arte Retórica para se rimar vários tipos de rima. ${ }^{5}$ Em sua edição, todas as composições pertencem ao teatro burlesco da época, exceto o manual de retórica.

Além da edição Levet, a edição Galliot Pré, intitulada As obras de Mestre Françoys Villon ${ }^{6}$ (VILLON, 1532), publicou-o com outras três composições burlescas: As refeições gratuitas de Françoys Villon e seus companheiros ${ }^{7}, 0$ monólogo do franco arqueiro de Baignollet, acompanhado do seu epitáfio e 0 diálogo dos senhores de Mallepaye e de Baillevent ${ }^{9}$. As Refeições gratuitas são um sermão jocoso imitando as Baladas em jargão de Villon. O monólogo do franco arqueiro de Baignollet, acompanhado do seu epitáfio é um monólogo dramático representando o tipo do soldado valentão que não tem medo de nada, exceto do perigo (COHEN, 1956, p. 258). O diálogo dos senhores de Mallepaye e de Baillevant é um diálogo burlesco entre as duas personagens do título.

Desde a primeira edição do corpus por Pierre Levet, o nome do autor é retirado do interior dos próprios poemas. Assim, as composições agrupadas em torno do nome próprio de Villon são designadas pela personagem assumida nos testamentos e nas formas fixas esparsas. Utilizado como uma etiqueta, o nome do autor serve para especificar os testamentos representando a personagem de mesmo nome em relação a outros testamentos burlescos da época, como O Testamento de Testa Vinhos, rei dos bêbados e o Testamento de Barreiz, capitão dos bretões, que também fazem parte da coletânea de Levet. Referido no título, o nome do autor serve para caracterizar esses testamentos como "de Villon".

\footnotetext{
4 Le grant testament Villon et le petit, son codicile, le jargon et ses balades.

Anotado sob a forma de um índice no exemplar da BNF estão os títulos destas obras reunidas na coletânea de Levet: "Pièces de ce recueil: 1) Pierre Pathelin, 1490; 2) Villon, 1489; 3) Testament de Barreiz, capitaine de Bretons; 4) Testament de Taste Vins, roi de Pions; 5) L'art de Rhétorique pour rimer en plusiers sortes de Rimes" (VILLON, 1489).

6 Les Fuvres de Maistre Françoys Villon.

Les Repues Franches de Françoys Villon et ses compagnons.
}

Le monologue de Franc Archer de Baignollet, avec son epitaphe.

Le dialogue des Messieurs de Mallapaye et de Baillevant. 
título da edição Levet foi retomado por diversas edições posteriores, em sua maioria incunábulos (como são chamadas as edições anteriores ao séc. XV), como as edições de Jean Dupré (LYON, 1490), de Germain Bineau (PARIS, 1490) e de Jehan Trepperel (PARIS, 1500). Em algumas edições posteriores ao séc. $\mathrm{XV}$, o nome completo passa a aparecer no título: nelas, o sobrenome Villon é precedido pelo prenome François e pelo qualificativo Mestre, como, por exemplo, na edição de Vve de G. Nyverd et de J. Nyverd, intitulada O Grande Testamento de Mestre Françoys Villon e o Pequeno. Seu Codicilo. O jargão e suas baladas ${ }^{10}$ (VILLON, 1525).

No início do séc. XIX, os editores modernos consideraram a atribuição tradicional do corpus a François Villon como autoevidente, segundo a concepção de autor como criador empírico e garantia da autenticidade da obra. A identidade do suposto autor foi descoberta no final do séc. XIX em documentos jurídicos do séc. XV sobre o indivíduo "François des Loges, também chamado de Villon" (VILLON, 1892, p. 133). Os títulos dos testamentos não foram mantidos pelos editores modernos. Na primeira metade do séc. XX, a edição Thuasne introduziu a mudança do título Pequeno Testamento para O Legado (Le Lais) (VILLON, 1923). Como o título Grande Testamento não precisava mais carregar o adjetivo grande para ser diferenciado do outro testamento, a obra passou a ser chamada simplesmente O Testamento (Le Testament).

Mas o nome do autor não designa o suposto autor empírico à época. Na baixa Idade Média, o autor é uma autoridade (auctoritas), designando a excelência em um gênero poético, com o seu estilo e convenções próprias. O corpus atribuído a François Villon se tornou uma autoridade poética nos sécs. XV e XVI na França, tendo sido imitado por diversos poetas líricos e burlescos do período. O nome Mestre François Villon é designado juntamente com outras autoridades poéticas nos Elencos de autores (Elenchus auctorum) das artes poéticas dos sécs. XV e XVI como, por exemplo, em Le Quintil Horacien, de Barthélémy Aneau (GOYET, 1990, p. 185).

Com base nas informações históricas atualmente disponíveis, o autor empírico do corpus atribuído a François Villon não pode ser conhecido. Esse corpus foi transmitido por dois suportes diferentes: por manuscritos e por edições impressas. Mesmo as suas mais antigas edições são póstumas: jamais publicada em vida pelo seu autor, edição alguma desse corpo poético é autorizada. A importância dos seus editores é tanto maior, quando se considera que o seu trabalho não se baseou em nenhum manuscrito autógrafo (escrito do punho do próprio autor), até porque todos os seus manuscritos, inclusive os mais antigos, são apógrafos (THUASNE, 1923).

O corpus de François Villon foi impresso aproximadamente vinte vezes desde a edição Levet realizada no final do séc. XV até a edição Marot em 1532 (Dop-Miller, 1991). Apesar de essas edições possuírem diversas variantes entre si e de nem sempre ser possível remontar essas variantes à edição Levet (Rychner, 1985, p. 529), todas as edições anteriores à edição Marot apresentam uma notável semelhança com a edição Levet. Com efeito, todas essas edições atribuem ao mesmo autor, apresentam o mesmo corpo poético, dispõem as composições na mesma ordem e retomam os mesmos títulos da edição Levet. Foi preciso esperar pela edição Marot para que os contornos do corpus fossem inteiramente modificados, como se verá a seguir.

Le Grant Testament Maistre Françoys Villon et le petit. Son Codicille. Avec le jargon et ses ballades.

Clément Marot: o principal editor antigo do corpus atribuido a François Villon 


\section{O prefácio de Clément Marot a sua edição}

O seu último editor no séc. XVI foi o poeta Clément Marot (1496-1544), que organizou em 1532, a pedido do rei François I (o poeta ocupava o cargo honorífico de valete de câmara do rei), a principal edição antiga do corpus de François Villon. Diferentemente da edição Levet, que é uma coletânea, a edição Marot é exclusivamente dedicada ao corpo poético de François Villon (VILLON, 1533). ${ }^{11}$ A edição Marot foi considerada a edição de referência desse corpus até as primeiras edições modernas. Em seu prefácio, Marot deplora tanto mais as condições precárias de sua obra quanto elogia o delicado engenho do poeta:

Aos Leitores: Entre todos os bons livros impressos da língua francesa, não se vê nenhum tão incorreto nem tão grosseiramente corrompido como o de Villon, e me desconcerta (visto que é o melhor poeta parisiense que há) como os impressores de Paris e os filhos da cidade não tiveram grande preocupação com ele [...] Eu não sou absolutamente da mesma região que ele: mas pelo amor de seu delicado engenho e em recompensa pelo que eu pude aprender com ele lendo as suas obras, eu fiz a elas o que eu gostaria que fosse feito às minhas, se elas tivessem tombado no mesmo inconveniente. Tanto eu encontrei nelas de mistura na ordem das estrofes e dos versos, no ritmo, na linguagem, na rima e no sentido, que não sei do que eu devo ter mais pena, da obra assim tão excessivamente estropiada, ou da ignorância dos que a imprimiram ${ }^{12}$ (VILLON, 1533, p. 73, tradução nossa).

Clément Marot vitupera os diversos editores anteriores pela negligência dispensada com o corpus de Villon. Ele lamenta ter encontrado a sua obra tão corrompida, tanto mais por considerá-lo um poeta de delicado engenho. Reconhecendo ter aprendido muito com Villon, ele apresenta a sua edição sob o signo da gratidão. Desse modo, Marot, que talvez tenha sido o principal poeta cortesão da primeira metade do séc. XVI na França, filia-se como herdeiro literário do poeta parisiense, como assinala a mais recente editora do corpus de François Villon (Cerquiglini-Toulet, 2005).

Marot afirma que, nas edições precedentes, a mistura na ordem das estrofes e dos versos, no ritmo, na linguagem, na rima e no sentido descaracterizaram por completo o corpus de Villon. No prefácio, Marot afirma que utilizou as edições mais antigas, em particular a edição Levet. Ele também reconhece ter se baseado em sua edição na memória "dos bons homens velhos que o conhecem de cor" e em deduções de seu "julgamento natural" (VILLON, 1893, p. 3).

11 Para a análise da edição Marot, será utilizada a edição revista um ano mais tarde, intitulada As Obras de François Villon de Paris, revistas e recolocadas em conjunto por Clément Marot, valete de câmara do rei (VILLON, 1533).

12

"Aux lecteurs: entre tous les bons livres imprimez de la langue françoise ne s'en veoit ung si incorrect ne si lourdement corrompu que celluy de Villon, et m'esbahy (veu que c'est le meilleur Poete parisien qui se trouve) comment les imprimeurs de Paris et les enfans de la ville n'en ont eu plus grand soing [...] Je ne suis (certes) en rien son voysin; mais, pour l'amour de son gentil entendement, et en recompense de ce que je puys avoir aprins de luy en lisant ses Oeuvres, j'ai faict à icelles ce que je vouldroys estre faict aux miennes, si elles estoient tombées en semblable inconvénient. Tant y ay trouvé de broillerie en l'ordre des coupletz et des vers, en mesure, en langaige, en la ryme et en la raison, que je ne sçay duquel je doy plus avoir pitié, ou de l'oeuvre ainsi ultrement gatée, ou de l'ignorance de ceux qui l'imprimérent". 
Visando restabelecer a melhor versão do corpus de Villon, Marot selecionou composições, reconstituiu a versificação de diversos versos, alterou a ordem das estrofes e até mesmo das composições. Imediatamente antes de citar como exemplo paradigmático da negligência dos primeiros editores a sua versão corrigida da estrofe XIII do Grande Testamento, Marot exorta à leitura da sua edição por meio da seguinte expressão: "Vede agora como ele foi vestido" ${ }^{13}$ (VILLON, 1893, p. 2). Essa passagem demonstra claramente que o editor entende as obras poéticas como a roupa vestida pelo seu autor, segundo a metáfora do textus. Ele também utiliza a metáfora do texto como corpo do autor, presente na própria expressão corpus:

E se alguém por acaso quiser dizer que nem tudo está assim recomposto como parece, eu the respondo desde já que, se ele estivesse tão danificado em sua pessoa como eu encontrei Villon em suas obras, não há cirurgião tão habilidoso que pudesse Ihe curar sem nenhuma cicatriz aparente ${ }^{14}$ (VILLON, 1893, p. 5, tradução nossa).

Segundo a metáfora do corpus, Marot se apresenta como o "cirurgião" de "Villon, machucado em suas obras". As metáforas do texto como a roupa vestida pelo autor e como o corpo do poeta pressupõem ambas a ideia de um sentido moral da obra, seja ele o corpo por trás da roupa utilizada pelo autor ou a alma no interior do corpo do poeta: por oposição à roupa, esse sentido é metaforizado pelo corpo; por oposição ao corpo, ele é metaforizado pela alma. No prefácio, Marot também utiliza a palavra intenção (intention): "Dei-me ao trabalho de restabelecer inteiramente (tanto quanto me for possível) a intenção do autor" 15 (VILLON, 1893, p. 4, tradução nossa).

Perpetuando a concepção biografista de Auguste Lanson, a medievista Cerquiglini-Toulet afirma que, tendo reconhecido a originalidade de Villon como o primeiro autor moderno, Marot teria estruturado a sua obra em torno da biografia do poeta (COSTA, 2014a, p. 86). Mas a expressão latina intenção do autor (intentio auctoris) é utilizada pelas artes poéticas da época (GARLANDE, 1974, p. 3) para designar o objetivo que, por trás da obra, orienta a sua invenção. Entendida como a verdade por trás do véu, como o corpo por trás da veste e como a alma por trás do corpo, a intenção do autor descoberta por Marot permitiu que a sua edição recompusesse a unidade por trás da obra de François Villon, como se pretende mostrar abaixo.

\section{A disposição cronológica dos testamentos}

A invenção constitui a primeira parte da retórica antiga e determina as partes subsequentes: a disposição, a elocução, a memória e a ação, respectivamente (ANONIME, 2003: 3). Para restabelecer a intenção do autor, a principal modificação introduzida pela edição Marot foi

\footnotetext{
13 "Or voyez maintenant comment il a este r'abillé".
}

14 "Et si quelqu'un d'adventure veult dire que tout ne soit racoustré ainsi qu'il appartient, je luy respons dès maintenant que, s'il estoit autant navré en sa personne comme j'ay trouvé Villon blessé en ses Fuvres, il n'y a si expert chirurgien qui le sceust panser sans apparence de cicatrice"

15 "J'ay prins peine de les refaire au plus près (selon mon possible) de l'intention de l'autheur".

Clément Marot: o principal editor antigo do corpus atribuido a François Villon 
a adoção de uma nova disposição que, alterando a estrutura das edições anteriores, explicita o sentido moral do corpus. Desde a edição Levet (1489) até a edição Galliot du Pré (1532), contemporânea da edição Marot, a primeira composição do corpus era o Grande Testamento de Villon ${ }^{16}$, poema longo contando mais de dois mil versos; última composição, o Pequeno Testamento ${ }^{17}$ é precedido por treze baladas esparsas e uma quadra (VILLON, 1489).

Apesar de essas quatorze formas fixas esparsas não se encaixarem propriamente na estrutura narrativa dos dois testamentos, Levet não as considera independentes deles. Pelo contrário, o editor parece considerá-las como um prolongamento do Grande Testamento, como sugere a rubrica introdutória a esse último: "Aqui começa o Grande codicilo em forma de testamento de Mestre François Villon"18 (VILLON, 1489). O codicilo é o diminutivo do termo latino para livro (codex), mas ele também podia designar um anexo no qual eram efetuadas as alterações ou anulações de testamentos reais.

O célebre Testamento de Jean de Meun (Jean de Meun, 1996), por exemplo, é concluído por um curto codicilo. Essa composição é o principal modelo imitado pelos testamentos de François Villon. Utilizado isoladamente, o termo codicilo designa o anexo ao Grande Testamento, que é formado pelas formas fixas esparsas, como sugere o pronome possessivo "seu codicilo" (son codicile) no título (ver nota 3). Assim, as quatorze formas fixas esparsas da edição Levet são designadas como parte de um codicilo que, inserido entre os dois testamentos, integra-as à ficção do testamento.

Na edição Levet, o termo codicilo também designa o livro (codex) em seu sentido material. Nesse sentido, o codicilo integra tanto o Grande Testamento quanto as formas fixas esparsas que se seguem a ele. Esse emprego de codicilo se deve ao fato de que o Grande Testamento contém baladas e rondós duplos intercalados às sequências de oitavas. É como se as formas fixas esparsas dispostas depois do Grande Testamento tivessem exatamente a mesma função que aquelas intercaladas no seu interior. Portanto, o codicilo criado por Levet procura encaixar as formas fixas esparsas aos dois testamentos poéticos, conferindo unidade à coletânea das composições de Villon.

O corpus publicado por Marot é menor do que o das edições anteriores, pois ele excluiu as Baladas em jargão, rompendo com toda a tradição editorial anterior, que as incluía (GUIRAUD, 1968, p. 22). Assim, a edição Marot contém apenas oito formas fixas esparsas, em vez de quatorze, como as edições anteriores. Além disso, ele suprime o termo codicilo, já que, em suas palavras, "ele [esse termo] não é de Villon" (VILLON, 1533, p. 5). Na edição Levet, a reunião das quatorze formas fixas esparsas num codicilo buscava integrá-las aos dois poemas longos de Villon. A exclusão do codicilo por Marot levou-lhe a separar da ficção testamentária as oito formas fixas esparsas que restaram na sua edição.

No lugar da estrutura testamentária, Marot introduziu a disposição cronológica, que tem a vantagem de evidenciar o sentido exemplar do corpus. Ao inserir as composições em ordem cronológica, Marot adota a estrutura própria do gênero da vida (uita) que, considerado subespécie da história, é utilizado desde a antiguidade para narrar anedotas de

16 Grant Testament Villon.

17 Petit Testament.

18 "Cy commence le Grant Codicille en testament maistre François Villon". 
personagens ilustres do passado, como imperadores, filósofos e oradores. $\bigcirc$ gênero não era desconhecido na época e foi particularmente explorado pela vasta literatura hagiográfica, que foi compilada por Jácopo de Varazze em sua Legenda Áurea para auxiliar os pregadores a redigirem os exemplos dos seus sermões (VARAZZE, 2003). ${ }^{19}$

De acordo com a estrutura narrativa oferecida pela vida, Marot reordenou completamente as composições, segundo a disposição Pequeno Testamento, Grande Testamento e formas fixas esparsas, respectivamente. Isso porque, de acordo com a ficção poética, o testador afirma que o Pequeno Testamento foi escrito em 1456 e o Grande Testamento em 1461. No prefácio à sua edição, Marot justifica a nova ordem adotada com base nas datas presentes nas próprias composições: "Finalmente, eu modifiquei a ordem do livro, e me pareceu mais razoável começar pelo Pequeno Testamento, já que ele foi composto cinco anos antes do outro" 20 (VILLON, 1533, p. 42, tradução nossa).

Os títulos dados aos testamentos de François Villon desde as primeiras edições foram mantidos por Marot. Mas o Pequeno Testamento passou a ser considerado a partir da sua edição como a primeira composição de Villon. Introduzido depois do Pequeno Testamento, o Grande Testamento é chamado por Marot de "segundo livro de Villon" (1533, p. 42). Depois dos testamentos, ele introduziu as oito formas fixas esparsas (sete baladas esparsas e uma quadra), que correspondem às oito formas fixas da edição Levet pertencentes ao codicilo, excetuadas as Baladas em jargão. Segundo o mesmo princípio cronológico, as formas fixas esparsas foram situadas em momentos específicos da vida da personagem.

Em vez de enumerar no título as diversas composições representando Villon, como fizeram os editores precedentes desde Levet, Marot intitulou o corpus de "As Obras de François Villon de Paris" ${ }^{21}$. Ele suprimiu o qualificativo mestre, presente no título de diversas edições anteriores, e vinculou o autor à sua cidade natal, chamando-o de "François Villon de Paris". Como foi visto na primeira passagem citada do prefácio, Marot elogia Villon como o melhor poeta parisiense da época, segundo a tópica da origem. A utilização da estrutura ficcional da vida permite demonstrar mais claramente o sentido moral do corpo poético, explicitando o percurso exemplar da personagem de François Villon, como se verá a seguir.

\section{O sentido espiritual do corpo poético}

As primeiras coletâneas de poemas medievais a adotarem o gênero da vida como princípio de organização foram as Vidas e razos de trobar. Nesses florilégios de canções de trovadores provençais, a narração da vida dos poetas pelos compiladores servia como uma introdução às canções. As canções eram ligadas a determinadas situações de enunciação narrativizadas na vida dos poetas. Porém as vidas também eram razos, já que os elementos utilizados nas vidas serviam para explicitar a interpretação realizada das canções pelos próprios compiladores.

19 Autonomizando-se em relação aos sermões, a vida dos santos se tornou um gênero importante da poesia em vernáculo desde o séc. XII, como demonstra a Vie de Saint Gilles (GUILLAUME DE BERNEVILLE, 2003).

20 "Finalement, j'ai changé l'ordre du livre, et m'a semblé plus raisonnable de le faire commencer par le Petit Testament, d'autant plus qu'il fut fait cinq ans avant l'autre"

Les Fuvres de François Villon de Paris. 
Baseadas em elementos retirados das próprias canções, as vidas e razos pretendiam orientar a leitura de canções que estavam originalmente destinadas à performance oral. Da mesma forma que as Vidas e razos de trobar, a Vita Nuova de Dante Alighieri é acompanhada por detalhadas rubricas, que servem como estrutura narrativa de sua coletânea de sonetos, baladas e canções. Na rubrica inicial, por exemplo, o poeta explica o título da sua coletânea, iniciada com o primeiro encontro do poeta com a amada Beatriz (DANTE, 1979, p. 153). As rubricas introduzidas por Dante também explicam-nas, como se ele fosse o comentador dos seus próprios poemas.

Igualmente baseadas em informações retiradas dos próprios poemas, as rubricas introduzidas por Marot no corpus de Villon contextualizam as composições, segundo os momentos cruciais da vida da personagem. Entendida como um gênero ficcional, a vida tem a função de organizar a coletânea de poemas, explicitar a situação dramática da personagem representada e oferecer ao leitor uma interpretação de conjunto a todo o corpus. Portanto, a introdução de rubricas explicativas foi a maneira encontrada por Marot para conferir unidade a este corpo poético constituído por dois poemas longos em forma de testamento e por formas fixas esparsas.

O editor elaborou uma grande quantidade de rubricas, inserindo, por exemplo, uma rubrica para cada uma das baladas e rondós duplos intercalados no interior do Grande Testamento. Retomadas mais tarde pelas edições posteriores de Villon, todos estes títulos e rubricas foram introduzidos por Marot. ${ }^{22}$ Assim, a linha utilizada por Marot para costurar a obra dilacerada do poeta parisiense foi precisamente a rubrica. As informações contidas nelas explicitam a maneira como as composições editadas foram interpretadas pelo editor.

Os testamentos são enunciados pela personagem real do célebre malfeitor François Villon no papel de testador. Essa personagem se baseia na figura tradicional do vilão arrependido, segundo o tipo bíblico do bom ladrão que, antes de ser crucificado ao lado de Cristo, arrepende-se pelos seus pecados e recebe a promessa da salvação (Luc. 23, 32). O Pequeno Testamento se situa antes da sua fuga de Paris para Angers, depois de Villon ter participado do roubo ao Colégio de Navarra. Ao inverter a ordem estabelecida entre as composições por todas as edições anteriores, Marot pretendeu utilizar o Pequeno Testamento como uma introdução ao Grande Testamento, oferecendo os elementos sobre a juventude da personagem do vilão.

Cinco anos mais tarde, o Grande Testamento retoma a mesma personagem no papel do testador moribundo, cuja libertação pelo rei Luís XI da traumática prisão de Meung produz uma reviravolta na vida da personagem, levando-lhe ao duro aprendizado do único bem verdadeiro: a salvação da alma (COSTA, 2014b, p. 6). As diversas referências ao Pequeno Testamento no Grande Testamento criam uma estrutura narrativa entre eles, representando o percurso do vilão desde o pecado, motivado pela inexperiência e pela incontinência da juventude, até a sua confissão diante da morte. $\bigcirc$ gênero do testamento é organizado

22 "Ballade des dames du temps jadis", "Ballade des seigneurs du temps jadis, suyvant le propos precedent", "Autre ballade a ce propos, en vieil langage Françoys", "Les regretz de la belle Heaulmyere ja parvenue a veillesse", "Ballade et doctrine de la Belle Heaulmière aux filles de joie", "Ballade que Villon feit a la requeste de sa mère, pour prier notre dame", "Ballade de Villon à s'amie", "Ballade et oraison", "Ballade que Villon donna a ung gentil home nouvellement marié, pour l'envoyer à son epouse par luy conquise à l'espée", "Ballade intitulée Les Contredictz de franc Gontier", "Belle Leçon aux enfans perduz", "Ballade de bonne doctrine a ceulx de mauvaise vie", "Ballade par laquelle Villon crye mercy a chascun" (VILLON, 1533). 
em torno de uma vida exemplar, como a literatura hagiográfica da época, mas, à diferença da vida dos santos, narrada linearmente em terceira pessoa, os testamentos são narrados retrospectivamente em primeira pessoa.

Portanto, o sentido moral da sua vida é interpretado pela própria personagem do vilão, cujos testamentos se apresentam como uma glosa das Sagradas Escrituras ao narrarem a história da salvação da perspectiva da personagem do bom ladrão (COSTA, 2014b, p. 11). Da mesma forma que o Novo Testamento renova a aliança estabelecida no Antigo Testamento, o Pequeno Testamento é corrigido pelo Grande Testamento. Inserido na sequência da vida de Villon, a unidade entre os testamentos é produzida pelo exemplo da personagem do vilão arrependido, segundo a cosmologia cristã da queda e redenção.

Como prescrevia a doutrina do véu, a ficção poética do Pequeno e do Grande Testamento glosa as Sagradas Escrituras, como se o bom ladrão também tivesse deixado o seu próprio testemunho. As formas fixas amplificam tópicas tratadas nos dois testamentos inseridos antes delas, como, por exemplo, a sua condenação ao enforcamento pelo roubo do Colégio de Navarra na Quadra e na Balada dos enforcados, o encarceramento do vilão na Epístola aos seus amigos e o pedido de clemência na Balada do Apelação. Na única quadra incluída entre as suas formas fixas esparsas, Villon se apresenta ao público, proferindo as suas últimas palavras antes do enforcamento:

Eu sou Franco, quanto me pesa!

Nasci em Paris (perto a Pontesa)

E verá com a corda tesa

Meu colo que o cú pesa... ${ }^{23}$

(VILLON, 2014, p. 226, tradução nossa)

Levet deu o seguinte título à composição: "Rondó que Villon fez quando foi condenado"24 (VILLON, 1489, p. 94). Isso talvez se deva ao fato de os rondós serem frequentemente compostos por rimas entrelaçadas, mas essa composição não constitui um rondó, que é definido pelas Artes de segunda retórica da época como um poema de oito versos, no qual o par de versos inicial é repetido uma vez e o primeiro inicial duas vezes (LANGLOIS, 1902, p. 20). Por isso, Marot corrige o título dado por Levet, definindo a composição como uma quadra: "A quadra que Villon fez quando ele foi condenado à morte" 25 (VILLON, 1533, p. 103).

Em quatro versos com rimas planas, Villon sintetiza a própria vida desde o seu nascimento em Paris até a morte iminente por enforcamento. François é também adjetivo, antiga pronúncia para francês. Segundo a tópica da origem, a França é apresentada como um mundo às avessas: a pequena cidade de Pontoise, notória por sua boa pronuncia do francês (Dufournet, 1992, p. 470), serve como ponto de referência para Paris. Assim, a nacionalidade francesa seria a causa da injustiça de que Franco (François) está prestes a sofrer. A aparente

23 "Je suis François, dont il me poise/ Né de Paris emprès Pontoise/ Et de la corde d'une toise/ Saura mon col que mon cul poise".

"Le rondeau que feit Villon quant il fut jugié".

25 "Le quatrain que feit Villon quant il fut jugé à mourir".

Clément Marot: o principal editor antigo do corpus atribuido a François Villon

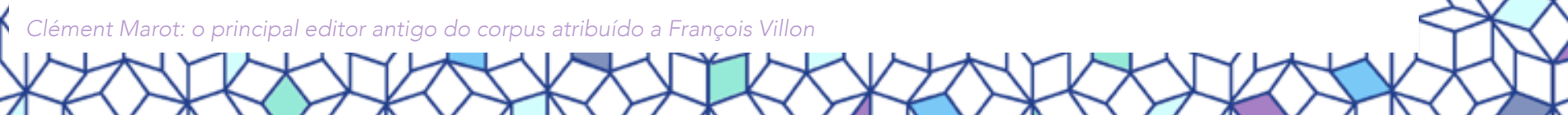


gravidade da cena de apresentação antes do enforcamento prepara a risada irônica provocada pela associação final entre colo [col] e cú [cul].

Assim, a principal vantagem oferecida pela adoção da estrutura narrativa da vida é a integração das formas fixas esparsas aos dois poemas longos em forma de testamento. A estrutura cronológica oferecida pela vida evidencia a maneira pela qual o corpus foi interpretado pelo seu editor e como eles deveriam ser recebidos pelo leitor. $\bigcirc$ editor é ao mesmo tempo comentador das obras, já que os contornos dados ao corpus se baseiam na sua própria interpretação dele. Assim, as duas atividades são complementares: enquanto o comentador retira o véu que encobre o sentido moral da obra, o editor tece novamente a trama para apresentá-la de maneira coerente ao leitor.

\section{Não a biografia de Villon, mas a vida do vilão}

Os primeiros editores das Obras de François Villon constituem um elo decisivo na movência (movence) de sua poesia (Zumthor, 1972, p. 73). Eles foram responsáveis pela sua atribuição a Villon, pelo seu primeiro agrupamento e pelos títulos dados aos testamentos e às formas fixas esparsas. Estabelecendo os principais contornos dados ao corpus, a edição Marot conferiu rubricas, reordenou e excluiu composições e até mesmo reconstituiu versos corrompidos. Mas a principal contribuição do editor foi a criação de uma disposição cronológica para o conjunto dos testamentos e das formas fixas esparsas, com base na vida da personagem representada nas composições.

Servindo de introdução à vida do vilão, o Pequeno Testamento narra os pecados que, cometidos na juventude, são confessados no Grande Testamento realizado antes da morte. A mesma disposição adotada pela edição Marot foi mantida por todos os editores modernos do corpus de François Villon desde o início do séc. XIX até a mais recente publicação pela prestigiosa Plêiade das Fuvres Complètes de François Villon, editadas e traduzidas por Jacqueline Cerquiglini-Toulet (VILLON, 2014). Embora as edições modernas tenham retomado a disposição estabelecida por Marot para o corpus, as suas edições interpretaram a vida como a biografia do poeta que teria supostamente escrito os poemas.

Com base nesses critérios biográficos, os editores modernos do corpus de Villon elidiram não apenas o caráter ficcional das composições, mas também o sentido moral que permitira a Marot unificar a sua edição em torno da vida exemplar da personagem do vilão arrependido, segundo a cosmologia cristã da queda e redenção. Por meio da reconstituição das suas primeiras edições, a intenção deste artigo foi precisamente retirar o véu fabuloso que, encobrindo a trama tecida entre o Pequeno e o Grande Testamento, orientou a recomposição da unidade do corpus atribuído a François Villon pelo seu principal editor antigo - o também poeta: Clément Marot de Cahors. 


\section{Referências Bibliográficas}

ALIGHIERI, D. Vida Nova, tradução de Paulo M. Oliveira e Blasio Demétrio. São Paulo: Abril Cultural, 1979.

ANONIME. Rhétorique à Herennius, texto estabelecido e traduzido por Guy Achard. Paris: Les Belles Lettres, 2003.

CERQUIGLINI, B. Éloge de la variante. Histoire de la philologie. Paris: Seuil, 1989.

CERQUIGLINI-TOULET, J. Marot et Villon, In: Villon et ses lecteurs, textes édités par Jean Dufournet, Michael Freeman et Jean Dérens. Paris: Champion, 2005, p. 19-31.

COSTA, D.P.P. Autor e personagem - François Villon e a nova crítica na França. Revista Criação \& Crítica, n. 12, 2014a, p. 76-87.

A punição "justa" do vilão: o sentido espiritual da tortura de François Villon. Revista Krypton, n. 4, 2014b, p. 4-13.

COHEN, G. Études d'Histoire du Théâtre en France au Moyen-Âge et à la Renaissance. Paris: Gallimard, 1956.

CHAMPION, P. La plus ancienne édition de François Villon. Paris: Editions des Quatre-Chemins, 1924.

DOP-MILLER, C. "Clément Marot et I'édition humaniste des Fuvres de François Villon", Romania. Paris, v. 112, n. 1-2, p. 217-242, 1991.

ECO, U. Arte e bellezza nell'estetica medievale. Milão: Bompiani, 1987.

GARLANDE, J., Parisiana Poetria: De arte prosayca, metrica et rithmica. New Haven: Yale University Press, 1974.

GOYET, F. Traités de poétique et de rhétorique de la Renaissance. Paris: Librairie Générale Française, 1990.

GUILLAUME DE BERNEVILLE. La Vie de Saint Gilles, traduction de Françoise Laurent. Paris: Champion, 2003.

GUIRAUD, P. Le jargon de Villon ou le gai savoir de la Coquille. Paris: Gallimard, 1968.

Jean de Meun. Testamento e Codicillo, etica, cultura, politica nella Parigi medievale, edição de S. Buzzetti Gallarati, Fiesole, 1996.

LANGLOIS, E. Recueil d'Arts de Seconde Rhétorique. Paris: Imprimerie nationale, 1902.

PSEUDO-FULGENCE "S. Fulgentii episcopi super Thebaiden". In: WOLF, E. (ed.), Virgile dévoilé, tradução e notas de Etienne Wolf. Villeneuve d'Ascq: Presses Universitaires du Septentrion, 2009.

RYCHNER, J. Du Saint-Alexis à François Villon: études de littérature médiévale. Genève: Droz, 1985.

THUASNE, L. «Notice Biographique», In: VILLON, F. Fuvres, edição de Louis Thuasne. Paris: A. Picard, 1923.

VARAZZE, J. Legenda áurea: vida de santos, tradução de Hilário Franco Júnior. São Paulo: Companhia das Letras, 2003.

VILLON, F. Le grant testament Villon et le petit, son codicile, le jargon et ses balades, edição de Pierre Levet. Paris, 1489. Disponível em:

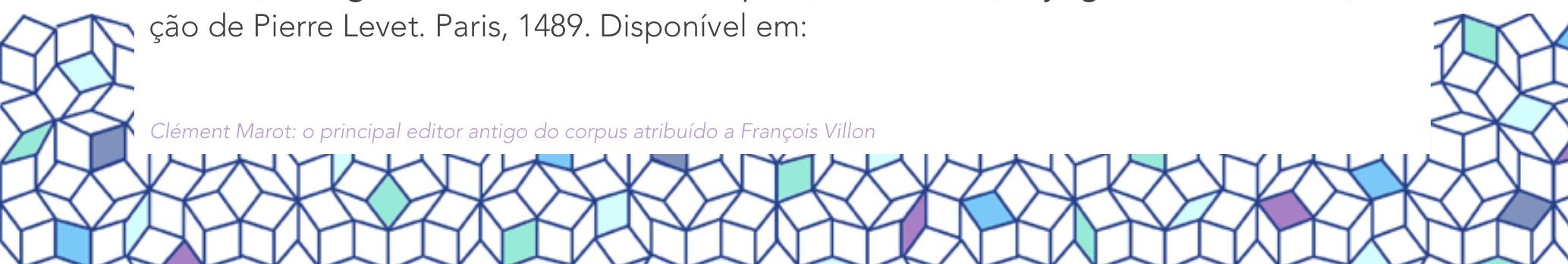


<http://gallica.bnf.fr/ark:/12148/bpt6k71046z.r=le+grant+testament+Villon+et+le+petit. langFR>.

Le grant testament Villon et le petit. Son Codicille. Le Jargon et ses Balades, edição de Jehan Trepperel. Paris, 1500.

Le Grant Testament Maistre Françoys Villon et le petit. Son Codicille. Avec le jargon et ses ballades, edição de Vve de G. Nyverd et de J. Nyverd. Paris, 1525.

. Les Fuvres de François Villon de Paris, edição de Clément Marot. Paris, 1533. Disponível em <http://gallica.bnf.fr/ark:/12148/bpt6k71466p.r=.langFR>.

. Fuvres de François Villon, edição Longnon. Paris: Librairie Alphonse Lemerre, 1892. . Fuvres, edição de Louis Thuasne. Paris: A. Picard, 1923.

. Le Lais Villon et les poèmes variés, edição Jean Rychner e Albert Henry, Genebra: Droz, 1977.

Poésies. Paris: GF-Flammarion, 1992.

. Fuvres complètes, edição e tradução de Jacqueline Cerquiglini-Toulet. Paris: Gallimard, 2014.

ZUMTHOR, P. Essai de Poétique médiévale. Paris: Seuil, 1972.

Recebido em: 16/08/2015 Aceito em: 06/11/2015

Referência eletrônica: COSTA, Daniel Padilha Pacheco da. Clément Marot: o principal editor antigo do corpus atribuído a François Villon. Criação \& Crítica, n. 15, p. 41-54, dez. 2015. Disponível em: <http://revistas.usp.br/criacaoecritica>. Acesso em: dd mmm. aaaa.

Clément Marot: o principal editor antigo do corpus atribuído a François Villon 